\title{
Effect of Physical and Chemical Parameters on the Activity of Purified Phosphatase Enzyme Produced by Bacillus cereus
}

\author{
Enas N. Danial ${ }^{1,2, *}$ and Maha I. Alkhalf ${ }^{1}$ \\ ${ }^{1}$ Biochemistry Department, Faculty of Science- Al Faisaliah King Abdulaziz University, Jeddah, Saudi Arabia \\ ${ }^{2}$ Chemistry of Natural and Microbial Products, National Research Center, Cairo, Egypt
}

\begin{abstract}
Phosphorus is one of the most important nutrients for plant growth and development. This study aimed to survey the optimum condition for phosphatase enzyme production, purified and studied its properties. Phosphatase enzyme activity was determined by end point method. Phosphatase enzyme was obtained from Bacillus cereus EME 66 isolate. The enzyme was purified and characterized, using a three-step purification procedure with 12.3-fold. The phosphatase enzyme was partially purified using ammonium sulfate fractionation followed by ultrafiltration. The acid phosphatase is a monomer protein purified gel filtration to 5.6 fold. Results showed that the optimum temperature for the purified enzyme activity was $60^{\circ} \mathrm{C}$ and it was stable at temperatures below $60{ }^{\circ} \mathrm{C}$. This enzyme was stable between $\mathrm{pH}$ 4.0-6.0, and the optimal $\mathrm{pH}$ activity was found to 5.0. The activity of the enzyme enhanced by heavy metals $\left(\mathrm{Fe}^{3+}, \mathrm{Cu}^{2+}\right.$, $\mathrm{Ca}^{2+}, \mathrm{Mg}^{2+}$ and $\mathrm{K}^{+}$). The enzyme activity was strongly inhibited by heavy metals $\mathrm{Zn}^{2+}$. The present article reveals on enzymatic characterization of acid phosphatase enzyme.
\end{abstract}

Keywords: Acid phosphatase, kinetic studies, enzyme purification, Bacillus cereus.

\section{INTRODUCTION}

Acid phosphatases (EC. 3.1.3.2) are group of enzymes that catalyze the hydrolysis of many phosphate monoesters and show $\mathrm{pH}$ optima on acid side $\mathrm{pH}$ 5-6 [1]. This enzyme is able to mineralize organic phosphorus into inorganic phosphorus $(\mathrm{Pi})$ that provides high $(\mathrm{P})$ level for plants. Soil phosphatases play a major role in the mineralization processes (dephosphorilation) of organic phosphorus substrates. The enzymes in soils originate from animal, plant and microbial sources and the resulting soil biological activity includes the metabolic processes of all organisms [2]. The microorganisms supply most of the soil enzyme activity under favorable conditions, [3]. Activity of phosphatase enzyme is affected by some factors, that is, the amount and kind of substrate [4], $\mathrm{pH}$, temperature, material of inhibitor and activator, concentration of enzyme and product, and also the kind of solvent used [5]. Besides, activity of soil phosphatase also the characteristic of physical and chemical of soil, that is, type of soil, content of organic matter, total nitrogen content, ratio of Carbon to Nitrogen $(\mathrm{C} / \mathrm{N})$ and content of total phosphorus [6]. Many microorganisms make enzymes in order to degrade complex substrates when preferred nutrients, such as glucose, ammonia, and $\mathrm{Pi}$, are not available. Although all of these are essential, cells can obtain the nutrients provided by enzymes, such as proteases, lipases, and nucleases, through the metabolism of a variety of carbon or nitrogen sources [7]. Phosphate,

*Address correspondence to this author at the Biochemistry Department, Faculty of Science- Al Faisaliah King Abdulaziz University, Jeddah, Saudi Arabia; Tel: 00966509630287; E-mail: enas_mahdy@yahoo.com however, cannot be synthesized by living organisms. Therefore, cells need to obtain phosphate from nucleic acids, and phosphorylated sugars, when $\mathrm{Pi}$ is limiting [8]. Thus, phosphatases are crucial enzymes for organism survival in nature as this enzyme can hydrolyze phosphate esters and provide $\mathrm{Pi}$. Because microorganisms can face intense competition for phosphate, it would not be surprising to find that many organisms produce phosphatases and have elaborate mechanisms for regulating their synthesis and activities [9]. What is surprising, however, is the diversity of phosphatases that are being discovered. Unlike many enzyme families in which subunit size, metal ion requirements, and substrate specificities are conserved, the few phosphatases that have been studied vary greatly [3]. For example, alkaline phosphatase monomers as small as $15.5 \mathrm{kDa}$ [10] and as large as $160 \mathrm{kDa}$ have been reported from two different halophilic strains [11]. Many extracellular phosphatases are monomers; however, the enzyme from Thermus aquaticus is a 143- kDa trimer [12]. Phosphatases have high specificities in their substrate, metal ion requirements, and $\mathrm{pH}$ ranges. Some, such as the one from Escherichia coli, are periplasmic, some are membrane associated [5], and some are extracellular [13]. This picture of vast biochemical diversity is emerging from limited studies with a few microorganisms. These preliminary results suggest that the properties of new phosphatases will be particularly fruitful, because there is a high probability of discovering new types with novel properties.

The present work deals with the purification of acid phosphatase enzyme from Bacillus cereus EME 66 and 
its characterization with respect to kinetic parameters, $\mathrm{pH}$ stability, thermal stability, enzyme concentration, and the effect of inhibitor and activator

\section{MATERIALS AND METHODS}

\section{Isolation and Identification of Acid Phosphatase Bacteria}

Among 30 different bacterial strains isolated from soil, a potent strain which gave a high yield of acid phosphatase was chosen for further study. The isolated strain was fully identified using morphological, biochemical and molecular biology technique as Bacillus cereus. This strain was routinely grown on (NA) agar medium [14] at $35^{\circ} \mathrm{C}$ for 72 hours. After this stage, the grown cells were collected in glycerol solution $(50 \%)$ and stored in Cryogen vial at $-80^{\circ} \mathrm{C}$ as master/working cells bank.

\section{Culture Conditions and Sample Preparation}

The liquid media was used for cultivation of Bacillus cereus EME 66 was composed of $(\mathrm{g} / \mathrm{l})$ : $(\% \mathrm{w} / \mathrm{v})$ : peptone 10.0; Dextrose 5.0; sodium phytate 1.0; yeast extract 5.0; $\mathrm{MgSO}_{4} 1.0 ; \mathrm{CaCl}_{2} 1.0(\mathrm{pH} 7.0) \mathrm{Kim}$ et al. [14]. The medium contents were sterilized by autoclaving at $121^{\circ} \mathrm{C}$. The broth medium $(50 \mathrm{ml}$ in 250 $\mathrm{ml}$ Erlenmeyer flasks) inoculated with $1 \mathrm{ml}$ pre-culture inoculum of Bacillus cereus EME 66, the inoculated flasks were incubated at $30^{\circ} \mathrm{C}$ with agitation speed 180 rpm for 5 days.

\section{Purification of Crud Extra Cellular Acid} Phosphatase Produced by Bacillus cereus EME 66

\section{Partial Purification of Acid Phosphatase}

The present experiment included the purification of extra cellular acid phosphatase using precipitation with ammonium sulphate, ethanol, and acetone methods according to the method of Greiner and Alminger [4].

\section{Precipitation Using Ultrafiltration}

The culture filtrate of about 2 liters was passed through Pellicon Cassette system with a membrane PLGC Cassette 10.000 NMWL. Low protein-binding.

\section{Gel Filtration of Extra Cellular Acid Phosphatase using Sephad ex G-100}

Sephadex G-100 was used as gel filtration for the enzyme purification. $7 \mathrm{ml}$ of extra cellular acid phosphatase obtained from ultra-filtration contain 200 $\mathrm{mg} / \mathrm{ml}$ protein was applied to a sephadex G-100 column chromatography $(108 \times 2.6 \mathrm{~cm})$ which had been equilibrated with $0.1 \mathrm{M}$ Tris buffer at $\mathrm{pH} 7.0$ at 11 ${ }^{\circ} \mathrm{C}$ [15]. Elution was carried out with the same buffer. 5 $\mathrm{ml}$ fractions were collected at flow rate of $33 \mathrm{ml} / \mathrm{h}$.

At first, the unbounded protein was removed by washing with the same buffer, and then enzyme was eluted by gradient elution using sodium chloride ( 0.0 to $1.0 \mathrm{M}$ ) in $0.1 \mathrm{M}$ Tris $\mathrm{HCl}$ buffer at $\mathrm{pH}$ 7.0. The flow rate was adjusted to $50 \mathrm{ml} / \mathrm{h}$ and $5 \mathrm{ml}$ fractions were collected from the effluent.

\section{Acid Phosphatase Activity and Protein Assay}

The activity of acid phosphatase was measured spectrophotometrically by monitoring the release of para-nitrophenol from paranitrophenyl phosphate (pNPP) at $400 \mathrm{~nm}$. A typical assay contained $330 \mathrm{mM}$ of $p$ NPP, $200 \mathrm{mM}$ sodium acetate buffer at $\mathrm{pH} 5,5 \mathrm{mM}$ calcium chloride, and an appropriate amount of spent culture medium, in a final volume of $1 \mathrm{ml}$. Reactions were performed at $30{ }^{\circ} \mathrm{C}$ and stopped by addition of 5 $\mathrm{ml}$ of $4 \mathrm{M}$ sodium hydroxide [16]. One unit of activity was defined as the amount of enzyme that hydrolyzed $1 \mathrm{mM}$ pNPP per min. Protein concentration was determined as described by Bradford [16].

\section{Characterization of Acid Phosphatase Activity}

The purified acid phosphatase was used for acid phosphatase activity characterization. All tests were repeated three times, each with triplicates.

\section{Effect of Temperature on the Stability of Acid Phosphatase Enzyme}

The thermal stability of the extra cellular purified enzyme was determined by storage the enzyme suspensions at different temperature in a water bath set $\left(20-80{ }^{\circ} \mathrm{C}\right)$ for different times (up to 24 hours), then the enzymes activity were determined in each case.

\section{Effect of $\mathrm{pH}$ on the Acid Phosphatase Stability}

In this experiment, $1 \mathrm{ml}$ of $0.15 \mathrm{M}$ acetate buffer at $\mathrm{pH}$ values ranged between 3.5-6 were stored at room temperature with $1 \mathrm{ml}$ of purified acid phosphatase enzyme solutions. The storage time was between 0 min. - 48 hours. The remains enzyme activity was then determined at Control conditions.

\section{Effect of Reaction Period on Purified Acid Phosphatase}

The effect of reaction time at $60{ }^{\circ} \mathrm{C}$ for acid phosphatase activities was also examined. Therefore, enzyme assay mixture was incubated for 1, 5, 10, 20, $30,40,50,60,70,80$ and $90 \mathrm{~min}$. 
Effect of Enzyme Concentrations of the Purified Extracellular Acid Phosphatase on their Activities

Different concentrations of the enzyme solutions ranging from 0.01 to $0.3 \mathrm{ml}(1 \mathrm{ml}$ of acid phosphatase enzyme contain $0.05 \mathrm{mg}$ protein) were added to $1 \mathrm{ml}$ of $0.2 \%$ p-Nitrophenyl Phosphate ( $p$ NPP) solution in 0.05 $\mathrm{M}$ citrate buffer at $\mathrm{pH} 6$ for $60 \mathrm{~min}$ at $60{ }^{\circ} \mathrm{C}$.

\section{Effects of Different lons and Cations on Acid Phosphatase Activity}

The metal ions used in the experiment were $\mathrm{MgCl}_{2}$, $\mathrm{MnCl}_{2}, \mathrm{ZnCl}_{2}, \mathrm{BaCl}_{2}, \mathrm{CuCl}_{2}, \mathrm{AlCl}_{3}, \mathrm{CaCl}_{2}, \mathrm{CoCl}_{2}, \mathrm{FeCl}_{2}$, $\mathrm{NiCl}_{2}, \mathrm{KCl}_{2}, \mathrm{MgCl}_{2}$, Na Florida, EDTA and DTT. These ions were added in concentrations 1 and $2 \mathrm{mM}$ to the reaction mixture to study their effect on the acid phosphatase activity. The control was carried out without adding activators or inhibitors.

\section{RESULTS}

\section{Purification of Crude Extracellular Acid} Phosphatase Produced by Bacillus cereus EME 66

\section{Partial Purification of Enzymes}

The present experiment included the purification of extra cellular acid phosphatase using precipitation with ammonium sulphate, ethanol and acetone or using ultra filtration methods. It is clear from the data presented in Table 1 that ammonium sulphate at concentration $30-60 \%$ gave a specific activity of 105 and $1.7 \mathrm{U} / \mathrm{mg}$ protein and purification fold was 0.71 .

Precipitation using acetone and ethanol also done and the results is showed in Table 1. It is clear that, the data showed that the precipitation of acid phosphatase using acetone at concentration to be $0-30 \%$ gave high specific activity than ethanol at concentration $0-30 \%$.

\section{Precipitation using Ultrafiltration}

The results showed in Table 2 two liters were concentrated to about $50 \mathrm{ml}$ which contain $10000 \mathrm{mg}$ protein (recovered) which represent about $64.10 \%$ of total protein while the specific activity was $2.4 \mathrm{U} / \mathrm{mg}$ proteins with purification fold 1.01 for acid phosphatase.

\section{Gel Filtration of Acid Phosphatase using Sephadex G-100}

The results in Figure 1 showed the pattern of gel filtration of acid phosphatase. The data illustrated the appearance of one peak for activity fraction (31-35), which it has total activity $1080 \mathrm{U}$ at $25 \mathrm{ml}$ and total protein $81 \mathrm{mg}$ with specific activity reached to $13 \mathrm{U} / \mathrm{mg}$ proteins.

Table 1: Partial Purification of Acid Phosphatase Produced by Bacillus cereus EME 66

\begin{tabular}{|c|c|c|c|c|c|c|c|c|}
\hline \multicolumn{2}{|c|}{$\begin{array}{l}\text { Purification } \\
\text { steps }\end{array}$} & $\begin{array}{c}\text { volume } \\
\text { (ml) }\end{array}$ & $\begin{array}{c}\text { Total } \\
\text { protein }\end{array}$ & $\begin{array}{c}\text { Protein } \\
\text { recovery (\%) }\end{array}$ & $\begin{array}{c}\text { Total units } \\
\text { (U/min) }\end{array}$ & $\begin{array}{c}\text { Units } \\
\text { recovery (\%) }\end{array}$ & $\begin{array}{l}\text { Specific } \\
\text { activity }\end{array}$ & Purification fold \\
\hline \multicolumn{2}{|c|}{ Culture filtrate } & 50 & 390 & 100 & 925 & 100 & 2.37 & 1 \\
\hline \multirow{3}{*}{ Acetone } & $0-30 \%$ & 50 & 100 & 25.6 & 215 & 23.2 & 2.15 & 0.90 \\
\hline & $30-60 \%$ & 50 & 190 & 48.7 & 110 & 11.8 & 0.58 & 0.24 \\
\hline & $60-90 \%$ & 50 & 22.2 & 5.5 & 00 & 00 & 00 & 00 \\
\hline \multirow{3}{*}{ Ethanol } & $0-30 \%$ & 50 & 109 & 28 & 202 & 21.8 & 1.85 & 0.78 \\
\hline & $30-60 \%$ & 50 & 200 & 51 & 136 & 14.7 & 0.68 & 0.29 \\
\hline & $60-90 \%$ & 50 & 00 & 00 & 00 & 00 & 00 & 00 \\
\hline \multirow{3}{*}{$\begin{array}{l}\text { Ammonium } \\
\text { sulphate }\end{array}$} & $0-30 \%$ & 50 & 195 & 50 & 122 & 13 & 0.62 & 0.26 \\
\hline & $30-60 \%$ & 50 & 150 & 38 & 254 & 27.4 & 1.7 & 0.71 \\
\hline & $60-90 \%$ & 50 & 00 & 00 & 00 & 00 & 00 & 00 \\
\hline
\end{tabular}

Table 2: Partial Purification of Acid Phosphatase Produced by Bacillus cereus EME 66 using Ultrafiltration

\begin{tabular}{|c|c|c|c|c|c|c|c|}
\hline $\begin{array}{c}\text { Purification } \\
\text { steps }\end{array}$ & $\begin{array}{c}\text { volume } \\
(\mathbf{m l})\end{array}$ & $\begin{array}{c}\text { Total } \\
\text { protein }\end{array}$ & $\begin{array}{c}\text { Protein } \\
\text { recovery (\%) }\end{array}$ & $\begin{array}{c}\text { Total units } \\
\text { (U/min) }\end{array}$ & $\begin{array}{c}\text { Units } \\
\text { recovery (\%) }\end{array}$ & $\begin{array}{c}\text { Specific } \\
\text { activity }\end{array}$ & Purification fold \\
\hline \hline Culture filtrate & 2000 & 15600 & 100 & 37000 & 100 & 2.37 & 1 \\
\hline Ultra-filtration & 50 & 10000 & 64.4 & 24000 & 64.8 & 2.4 & 1.01 \\
\hline
\end{tabular}




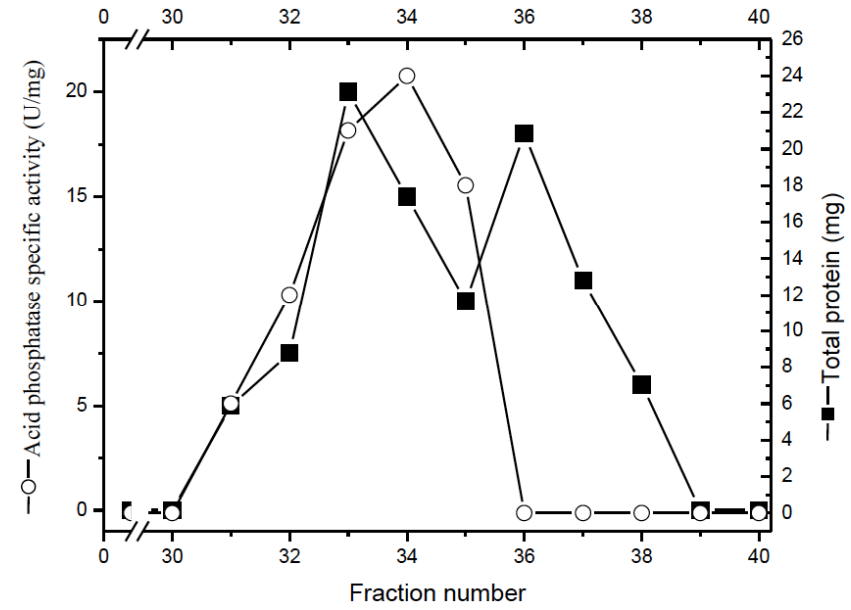

Figure 1: Purification of extracellular acid phosphatase by using sephadex G-100.

The active fraction of acid phosphatase was chosen for the check of their purity on polyacrylamide gel electrophoresis. Figure 2 showed that acid phospha- tase was homogenous as it migrated as single protein band.

\section{Summarized Purification Steps of Acid Phosphatase}

Purification steps acid phosphatase from Bacillus cereus EME 66 is summarized in Table 3 . The cultural filtrate obtained after centrifugation of the fermentation broth was subjected to ultrafiltration using Pellicon Cassette system with a membrane PLGC Cassette 10.000 NMWL, low protein-binding. This step yielded 1.01 fold of purification for acid phosphatase. It was chromatographed on sephadex G100 column and the enzymes were eluted with tris $\mathrm{HCl}$ buffer of $\mathrm{pH} 7.0$.

This procedure showed that the acid phosphatase was purified approximately 5.6 fold from the culture filtrate with a specific activity about $13.3 \mathrm{U} / \mathrm{mg}$ proteins. Figure 2 showed that acid phosphatase resulted from
1

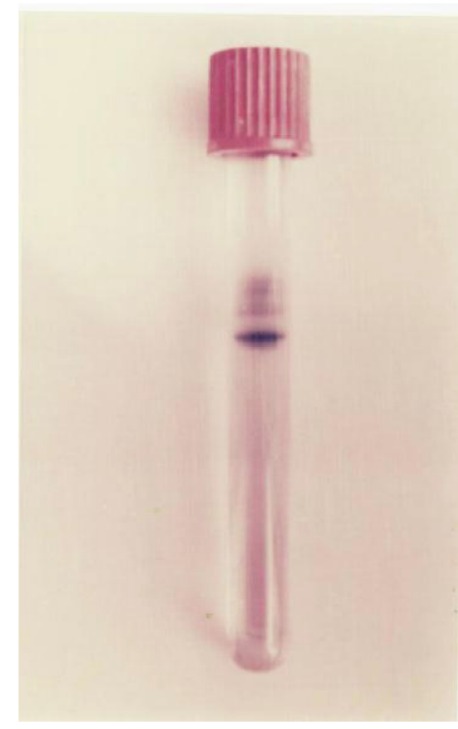

2

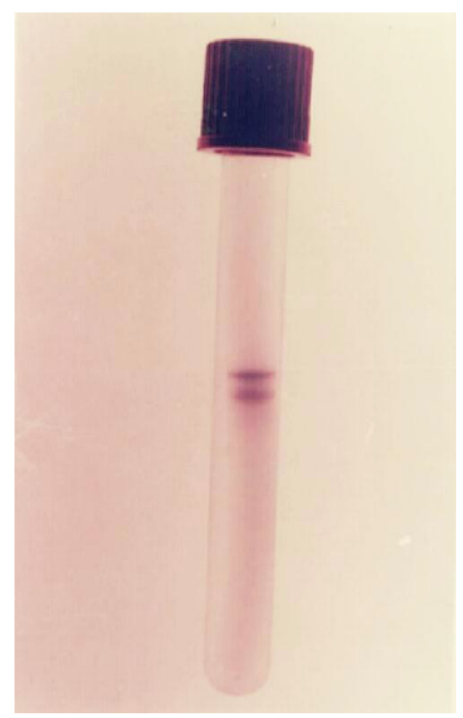

3

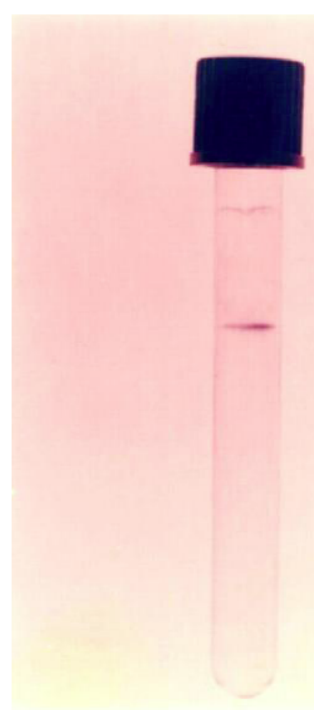

Figure 2: Purification steps of acid phosphatase. (1) Crude enzyme, (2) partially purified enzyme by ultra-filtration, (3) the enzyme of acid phosphatase separated on sephadex $\mathrm{G} 100$.

Table 3: Purification Steps of Acid Phosphatase

\begin{tabular}{|c|c|c|c|c|c|c|c|}
\hline $\begin{array}{c}\text { Purification } \\
\text { Steps }\end{array}$ & $\begin{array}{c}\text { Volume } \\
(\mathbf{m l})\end{array}$ & $\begin{array}{c}\text { Total } \\
\text { protein }\end{array}$ & $\begin{array}{c}\text { Protein } \\
\text { Recovery (\%) }\end{array}$ & $\begin{array}{c}\text { Total activity } \\
\text { (U/min) }\end{array}$ & $\begin{array}{c}\text { Units } \\
\text { recovery (\%) }\end{array}$ & $\begin{array}{c}\text { Specific } \\
\text { activity }\end{array}$ & Purification fold \\
\hline \hline Culture filtrate & 40 & 312 & 100 & 740 & 100 & 2.37 & 1 \\
\hline Ultra-filtration & 1 & 200 & 64.1 & 480 & 64.8 & 2.4 & 1.01 \\
\hline & $\mathrm{F}(1-21)$ & 145.8 & 46.8 & 00 & 00 & 00 & 00 \\
Sephadex & $\mathrm{F}(22-30)$ & 267 & 85.5 & 00 & 146 & 13.3 & 00 \\
G-100 & F(31-35) & 81 & 26 & 1080 & 00 & 00 & 00 \\
& F(36-60) & 119.1 & 38 & 00 & 00 \\
\hline
\end{tabular}


sephadex G100 column chromatography was migrated as single protein band.

\section{Properties of Purified Acid Phosphatase Produced by Bacillus cereus EME 66}

\section{Effect of Temperature on the Stability Acid Phosphatase}

The thermal stability of the extracellular purified acid phosphatase was determined by incubation the enzyme suspensions at different temperature in a water bath (between 20 and $80^{\circ} \mathrm{C}$ ) for different periods (up to 24 hours), then the enzyme activities were determined in each case.

The results in Table 4 showed that the stability of acid phosphatase was depending on the temperature and the time. In most cases, the loss in acid phosphatase activities was increased by increasing the temperature and the storage time.
The pure acid phosphatase was stable at temperature $20,30{ }^{\circ} \mathrm{C}$ and $40{ }^{\circ} \mathrm{C}$ for 24 hours. At temperature $50{ }^{\circ} \mathrm{C}$ the enzyme lost $11 \%$ of its activity after 24 hours. The acid phosphatase completely lost its activity at $70^{\circ} \mathrm{C}$ after $90 \mathrm{~min}$ or after $30 \mathrm{~min}$ at $75^{\circ} \mathrm{C}$ and after $5 \mathrm{~min}$ at $80^{\circ} \mathrm{C}$.

\section{Effect of pH on Acid Phosphatase Stability}

In this experiment, $1 \mathrm{ml}$ of $0.15 \mathrm{M}$ acetate buffer at $\mathrm{pH}$ values ranged between 3.5-6 were stored at room temperature with $1 \mathrm{ml}$ of purified acid phosphatase Enzyme solutions

The remain activity of purified acid phosphatase enzyme was then determined at $60{ }^{\circ} \mathrm{C}$ and $\mathrm{pH} 6$, and control was carried out using $\mathrm{pH} 6$

The results recorded in Table $\mathbf{5}$ indicated that the stability pure acid phosphatase showed stability at $\mathrm{pH} 5$

Table 4: Effect of Temperature on Acid Phosphatase Stability

\begin{tabular}{|c|c|c|c|c|c|c|c|c|c|c|c|c|c|c|}
\hline \multirow{3}{*}{ Temp. ${ }^{\circ} \mathrm{C}$} & \multicolumn{14}{|c|}{ Relative activity (\%) } \\
\hline & \multicolumn{9}{|c|}{ Time (minutes) } & \multicolumn{5}{|c|}{ Time (hours) } \\
\hline & 0 & 5 & 10 & 20 & 30 & 40 & 50 & 60 & 90 & 2 & 4 & 6 & 12 & 24 \\
\hline 20 & 100 & 100 & 100 & 100 & 100 & 100 & 100 & 100 & 100 & 100 & 100 & 100 & 100 & 100 \\
\hline 30 & 100 & 100 & 100 & 100 & 100 & 100 & 100 & 100 & 100 & 100 & 100 & 100 & 100 & 100 \\
\hline 40 & 100 & 100 & 100 & 100 & 100 & 100 & 100 & 100 & 100 & 100 & 100 & 100 & 100 & 100 \\
\hline 50 & 100 & 100 & 100 & 100 & 100 & 100 & 100 & 100 & 100 & 100 & 100 & 100 & 100 & 89 \\
\hline 55 & 100 & 100 & 100 & 100 & 100 & 100 & 100 & 100 & 100 & 100 & 91 & 84 & 82 & 76 \\
\hline 60 & 100 & 100 & 100 & 100 & 100 & 100 & 100 & 95 & 86 & 71 & 65 & 53 & 41 & 20 \\
\hline 65 & 100 & 100 & 100 & 100 & 100 & 96 & 83 & 75 & 69 & 64 & 59 & 53 & 34 & 14 \\
\hline 70 & 100 & 91 & 85 & 72 & 50 & 34 & 10 & 2 & 0 & 0 & 0 & 0 & 0 & 0 \\
\hline 75 & 100 & 83 & 73 & 50 & 0 & 0 & 0 & 0 & 0 & 0 & 0 & 0 & 0 & 0 \\
\hline 80 & 100 & 0 & 0 & 0 & 0 & 0 & 0 & 0 & 0 & 0 & 0 & 0 & 0 & 0 \\
\hline
\end{tabular}

Table 5: Effect of pH on Acid Phosphatase Stability

\begin{tabular}{|c|c|c|c|c|c|c|c|c|c|c|c|}
\hline \multirow{3}{*}{ pH Value } & \multicolumn{11}{|c|}{ Acid phosphatase Relative activity (\%) } \\
\hline & \multicolumn{5}{|c|}{ Time (minutes) } & \multicolumn{6}{|c|}{ Time (hours) } \\
\hline & $\mathbf{0}$ & 15 & 30 & 45 & 60 & 2 & 4 & 8 & 16 & 24 & 48 \\
\hline 3 & 86 & 65 & 33 & 8 & 0 & 0 & 0 & 0 & 0 & 0 & 0 \\
\hline 3.5 & 91 & 82 & 68 & 42 & 30 & 18 & 6 & 0 & 0 & 0 & 0 \\
\hline 4 & 100 & 100 & 100 & 100 & 100 & 82 & 63 & 48 & 22 & 9 & 4 \\
\hline 4.5 & 100 & 100 & 100 & 100 & 100 & 100 & 100 & 100 & 95 & 81 & 76 \\
\hline 5 & 100 & 100 & 100 & 100 & 100 & 100 & 100 & 100 & 100 & 100 & 100 \\
\hline 5.5 & 100 & 100 & 100 & 100 & 100 & 100 & 100 & 100 & 100 & 100 & 100 \\
\hline 6 & 100 & 100 & 100 & 100 & 100 & 100 & 100 & 100 & 92 & 85 & 78 \\
\hline 6.5 & 100 & 100 & 100 & 94 & 85 & 71 & 65 & 59 & 50 & 46 & 34 \\
\hline
\end{tabular}


to 5.5 for 48 hours and lost some of its activity at $\mathrm{pH}$ 6.0 at 16 hours of incubation. At pH 3 and 3.5, acid phosphatase was completely inhibited at 60 min and 8 hours respectively. At $\mathrm{pH} 4.5$ the enzyme was stable till 8 hours and partially lost its activity by increasing the time of storage.

\section{Effect of Reaction Period on Purified Acid Phosphatase}

The effect of incubation time on enzyme activity was monitored by incubating the enzyme reaction mixture in different time period (10 to $90 \mathrm{~min}$ ). The results in Figure 3 showed that the rate of $p N N P$ hydrolysis of reached its maximum at $60 \mathrm{~min}$, then decreased with the incubation time. The activity of acid phosphatase was measured at different periods of incubation (10 to $90 \mathrm{~min}$ ). The enzyme activity slowly increased from 10 to $70 \mathrm{~min}$. The maximum of enzyme activity was obtained at $70 \mathrm{~min}$ and after that, the activity gradually decreased.

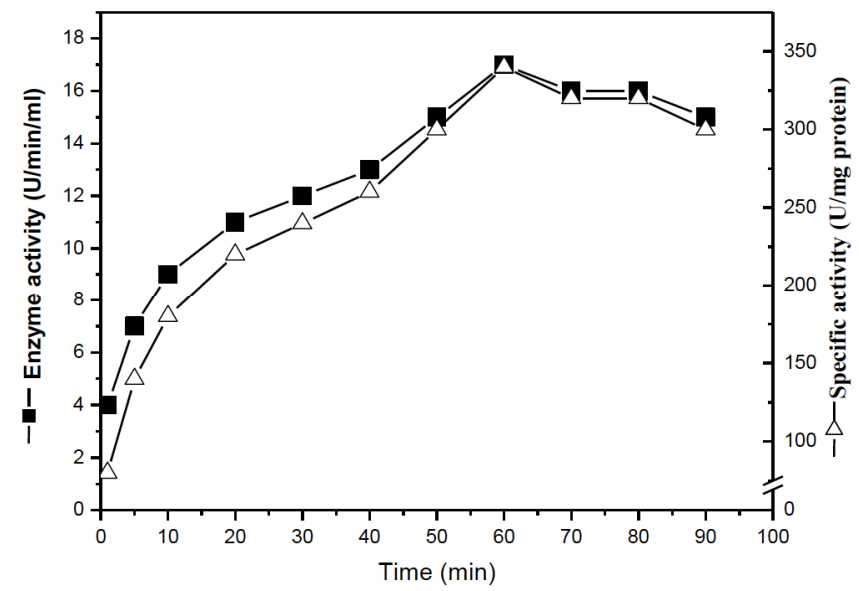

Figure 3: Effect of the incubation period on the purified acid phosphatase.

\section{Effect of Enzyme Concentrations of the Purified Extracellular Acid Phosphatase on their Activities}

The data recorded in Figure 4 showed that the acid phosphatase activity was increased gradually with the increase of enzyme concentrations up to $0.1 \mathrm{ml}$ enzyme, at which the acid phosphatase showed a maximum activity (500 U/mg proteins). Above this concentration the specific activity decreased.

\section{Effect of Different Concentrations of Activators and Inhibitors on the Acid Phosphatase Activities}

In this experiment, the metal ions used in the experiment were $\mathrm{MgCl}_{2}, \mathrm{MnCl}_{2}, \mathrm{ZnCl}_{2}, \mathrm{BaCl}_{2}, \mathrm{CuCl}_{2}$, $\mathrm{AlCl}_{3}, \mathrm{CaCl}_{2}, \mathrm{CoCl}_{2}, \mathrm{FeCl}_{2}, \mathrm{NiCl}_{2}, \mathrm{KCl}_{2}, \mathrm{MgCl}_{2}, \mathrm{NaF}$, EDTA and DTT. They were added in concentrations 1 and $2 \mathrm{mM}$ to the reaction mixture to study their effect on the acid phosphatase activities and their substrates. The results recorded in Table 6 showed that the enzyme activity was greatly inhibited by $\mathrm{FeCl}_{2}, \mathrm{Na}$ Florida, EDTA, $\mathrm{AlCl}_{3}, \mathrm{ZnCl}_{2}$ and DTT. On the other hand the addition of $\mathrm{MnCl}_{2}, \mathrm{BaCl}_{2}, \mathrm{CuCl}_{2}$ and $\mathrm{NiCl}_{2}$ showed partial inhibition of acid phosphatase while, $\mathrm{MgCl}_{2}, \mathrm{CoCl}_{2}$, and $\mathrm{KCl}_{2}$ had no effect on the both enzymes. Moreover, $\mathrm{CaCl}_{2}$ made a slight increase in the activity of phytase when added at concentration in $1 \mathrm{mM}$, the activity was decreased with decreasing the concentration, but there is no effect on acid phosphatase activity.

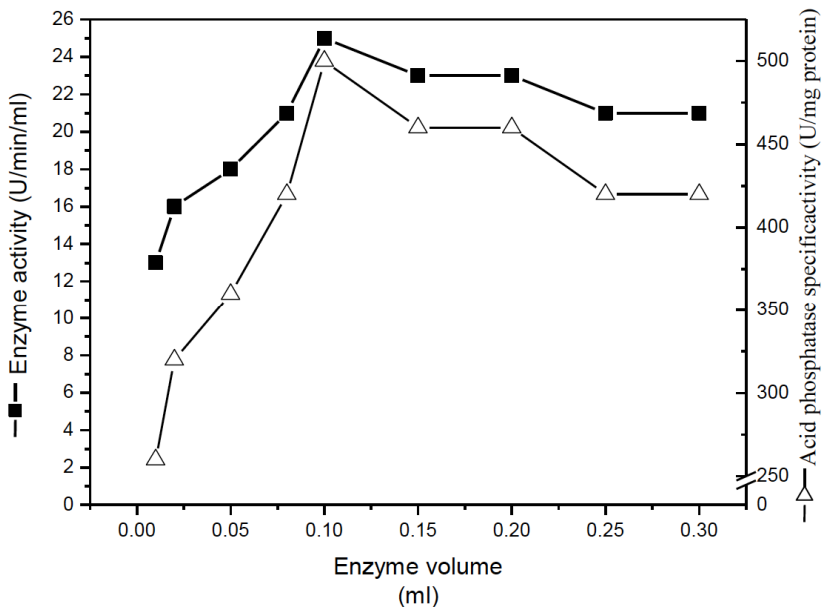

Figure 4: Effect of enzyme concentrations of the purified extracellular acid phosphatase on their activities.

Table 6: The Effect of Different Concentrations of Activators and Inhibitors on the Acid Phosphatase Activities

\begin{tabular}{|c|c|c|}
\hline \multirow{2}{*}{ Additive } & \multicolumn{2}{|c|}{ Acid phosphatase Relative activity \% } \\
\cline { 2 - 3 } & $\mathbf{1 ~} \mathbf{~ M}$ & $\mathbf{2} \mathbf{~ m M}$ \\
\hline \hline Control & 100 & 100 \\
\hline $\mathrm{MgCl}_{2}$ & 98 & 91 \\
\hline $\mathrm{MnCl}_{2}$ & 93 & 87 \\
\hline $\mathrm{ZnCl}_{2}$ & 78 & 70 \\
\hline $\mathrm{BaCl}_{2}$ & 86 & 83 \\
\hline $\mathrm{CuCl}_{2}$ & 89 & 80 \\
\hline $\mathrm{AlCl}_{3}$ & 78 & 69 \\
\hline $\mathrm{CaCl}_{2}$ & 100 & 99 \\
\hline $\mathrm{CoCl}_{2}$ & 100 & 95 \\
\hline $\mathrm{FeCl}_{2}$ & 60 & 43 \\
\hline $\mathrm{NiCl}_{2}$ & 91 & 89 \\
\hline $\mathrm{KCl}$ & 96 & 91 \\
\hline $\mathrm{MgCl}_{2}$ & 84 & 68 \\
\hline $\mathrm{EDTA}$ & 78 & 65 \\
\hline $\mathrm{NaF}^{2}$ & 69 & 52 \\
\hline $\mathrm{DTT}$ & 74 & 56 \\
\hline & & \\
\hline
\end{tabular}




\section{DISCUSSION}

Bacilli have been widely used in many fermentation industries since many years [16]. This based on their high capacity for the production of bioactive metabolites. In addition, they also considered as one of the best enzyme biofactories based not only their ability to produce wide range of enzymes in high concentration but also due to their high secretion capacity and export of protein to the fermentation medium [17-21].

The present study is demonstrated the purification and characterization of acid phosphatases from Bacillus cereus EME 66. First attempts to separate acid phosphatase activity by the one-step procedure described by Tham [22], for acid phosphatase purification was unsuccessful. This procedure was based on the difference of isoelectric points of enzyme. When chromatographed on a strong cationicexchanger (SP-Trisacryl) column at $\mathrm{pH} 4.5$, soybean phosphatase was retained on the column, whereas acid phosphatase was excluded. Under the same conditions, enzyme activities were retained and eluted at the same saline concentration.

Purification of enzyme phosphatase was by ammonium sulfate precipitation followed by dialysis. The optimum temperature for enzyme purified activity was $40{ }^{\circ} \mathrm{C}$ and the enzyme was stable at temperatures below $60{ }^{\circ} \mathrm{C}$ when preincubated at various temperatures for $30 \mathrm{~min}$. Cheng and Yang, reported Thermo-tolerant phosphate-solubilizing microbes with six types of enzyme activities and three types of inorganic phosphate-solubilizing activities at 25 and $50^{\circ} \mathrm{C}$ were isolated from the composts and biofertilizers [1]. Acid phosphatase of Penicillium citrinum (coldtolerant fungus) had an optimum temperature of $60^{\circ} \mathrm{C}$. The dried enzyme extract is stable at a temperature of up to $50^{\circ} \mathrm{C}$ for at least $1 \mathrm{~h}$ [4]. In addition, $\mathrm{pH}$ had a statistical effect on the activity of acid phosphatase where, in more acid Acid phosphatase isolated from Burkholderia gladioli was stable after $6 \mathrm{~h}$ of incubation at $45{ }^{\circ} \mathrm{C}$ in $100 \mathrm{mM}$ acetate buffer at $\mathrm{pH}$ 6.0. The rate of hydrolysis enzyme reached a maximum at $\mathrm{pH} 6.0$ [23].

The phosphatases were found to be thermostable and acid tolerant the enzyme was thermostable since the retained their full activity even after 2 hours of exposure to the temperature range 40 to $65^{\circ} \mathrm{C}$. Our finding is in Agreement with the previous report which showed thermostability of acid phosphatase from $A$. niger up to $70^{\circ} \mathrm{C}[24,25]$.
In the reaction medium the incubation time might be due to stability of enzyme. The enzyme was also found to be thermostable with $60{ }^{\circ} \mathrm{C}$ as its optimum temperature. Enzyme activity was decreased after 60 ${ }^{\circ} \mathrm{C}$ might be due to irreversible denaturation. Acid phosphatase (from Red kidney bean purple) had optimal enzyme activity at $60{ }^{\circ} \mathrm{C}$ [26]. The acid phosphatase from soybean seeds was shown to be heat stable [12]. However, the obtained temperature 70 ${ }^{\circ} \mathrm{C}$ for acid phosphatase in germinated mung bean seed was higher than the value obtained for the enzyme in cotton seedling [27] and in Vigna aconifolia [28].

Large number of metal ions was tested for their effects on the acid phosphatase activity (Table 4). The enzyme was not affected by $\mathrm{Ca}^{+2}, \mathrm{Mg}^{+2}, \mathrm{Ba}^{+2}, \mathrm{Mn}^{+2}$ and $\mathrm{Co}^{+2}$ in the reaction mixture, indicating that divalent cations are not required for the catalytic activity of this enzyme. A similar neutral effect of these ions was also reported for acid phosphatases isolated from axes and cotyledons of germinating soybeans [22].

\section{REFERENCES}

[1] Chang $\mathrm{CH}$, Yang SS. Thermo-tolerant phosphate-solubilizing microbes for multi-functional biofertilizer preparation. Bioresour Technol 2009; 100: 1648-58. https://doi.org/10.1016/j.biortech.2008.09.00`9

[2] Spiers G A, McGill WB. Effects of phosphorus addition and energy supply on acid phosphatase production and activity in soils. Soil Biol and Biochem 1979; 11(1): 3-8. https://doi.org/10.1016/0038-0717(79)90110-X

[3] Fitriatin BN, Arief DH, Simarmata T, Santosa DA, Joy B. Phosphatase-producing bacteria isolated from Sanggabuana forest and their capability to hydrolyze organic phosphate. J Soil Sci Environm Mang 2011; 2(10): 299-303. https://doi.org/10.5897/JSSEM

[4] Gawas SP, Singh SM, Naik S, Ravindra R. High-temperature optima phosphatases from the cold-tolerant Arctic fungus Penicillium citrinum. Polar Res 2012; 31:1-7. http://dx.doi.org/10.3402/polar.v31i0.11105

[5] Hu XJ, Li ZJ, Cao YC, Zhang J, Gong YX, Yang YF. Isolation and identification of a phosphate-solubilizing bacterium Pantoea stewartii subsp. stewartii g6, and effects of temperature, salinity, and $\mathrm{pH}$ on its growth under indoor culture conditions. Aquaculture Int 2010; 18(6): 1079-91. https://doi.org/10.1007/s10499-010-9325-8

[6] Mahesh M, Somashekhar R, Preenon B, Puttaiah ET. Optimization for the Production of Extracellular Alkaline Phosphatase from Proteus mirabilis J. Bioproc Biotech 2015; 5(3): 1-5. https://doi.org/10.4172/2155-9821.1000213

[7] Kerovuo J, Tynkkynen S. Expression of Bacillus subtilis phytase in Lactobacillus plantarum 755. Lett Appl Microbiol 2000; 30(5): 325-9. https://doi.org/10.1046/j.1472-765x.2000.00660.x

[8] Jain R, Garg V, Dangwal K, Madhuri KL. Purification and characterization of acid phosphatase from monocrotophos (MCP) hydrolyzing Aspergillus niger ITCC 7782.10 isolated from local agricultural field. Turk J Biochem 2013; 38(4): 396402.

https://doi.org/10.5505/tjb.2013.19870 
[9] Ruangsanka S. Identification of phosphate-solubilizing fungi from the asparagus rhizosphere as antagonists of the root and crown rot pathogen Fusarium oxysporum. Science Asia 2014; 40: 16-20.

https://doi.org/10.2306/scienceasia1513-1874.2014.40.016

[10] Kannaiyram S, Vedhachalam $R$, Thanigaimalai $M$. Production and Characterization of Alkaline Phosphatase Produced by Bacillus Species. J Appl Biol Biotechnol 2015; 3(5): 31-4.

https://doi.org/10.7324/JABB.2015.3506

[11] Surchandra TH, Roy SS, Rakesh SN, Sahoo MR, Prakash N. Partial purification and biochemical characterization of acid phosphatase from germinated mung bean (Vigna radiata) seeds. Afr J Biotechnol 2012; 11(103): 16777-82. https://doi.org/10.5897/AJB12.2552

[12] Pradhan N, Sukla LB. Solubilization of inorganic phosphates by fungi isolated from agriculture soil. Afr J Biotechnol 2006; 5(10): 850-4.

\section{https://doi.org/10.5897/AJB2006.000-5050}

[13] Rombola TH, Pedrinho EA, Macedo LEG, Gonçalves AM, Santos LF, Pizauro JM. Identification and enzymatic characterization of acid phosphatase from Burkholderia gladioli. BMC Res Notes 2014; 7: 221. https://doi.org/10.1186/1756-0500-7-221

[14] Kim DH, Oh BC, Choi WC, Lee JK, Oh TK. Enzymatic evaluation of Bacillus amyloliquefaciens phytase as a feed additive. Biotechnol Lett 1999; 2: 925-7. https://doi.org/10.1023/A:1005602717835

[15] Greiner R, Konietzny U, Jany KD. Purification and properties of a phytase from rye. J Food Biochem 1998; 22:143-61. https://doi.org/10.1111/j.1745-4514.1998.tb00236.x

[16] Sarmidi MR, El Enshasy HA. Biotechnology for wellness industry: Concepts and biofactories. Int $\mathrm{J}$ Biotechn Well Ind 2012; 1: 3-28. http://dx.doi.org/10.6000/1927-3037.2012.01.01.01

[17] Beshay U, El Enshasy H. Production of $\alpha$-amylase by Bacillus amyloliquefaciens during batch cultivation in shake flask and stirred tank bioreactor. Deutsche Lebensmittel Rundshau 2002; 98: 5-9.

[18] El Enshasy H, Aboul-Enein A, Helmy S, El Azaly Y. Optimization of the industrial production of alkaline protease by Bacillus licheniformis in different production scales. Aust $J$ Basic Appl Sci 2008; 2: 583-93.

[19] Abdel Fattah YR, El Enshasy HA, Soliman NA, El-Gendi H. Bioprocess development for the production of alkaline protease by Bacillus pseudoformus Mn6 through statistical experimental designs. J Microbiol Biotechnol 2009; 19: 37886.

http://dx.doi.org/10.4014/jmb.0806.380

[20] Esawy M, Mansour S, Ahmed E, Naziha M, El Enshasy H. Characterization of extracellular dextranase from novel halophilic Bacillus subtilis NRC-B233b a mutagenic honey isolate under solid state fermentation. Elect J Chem 2012; 9:1494-510. http://dx.doi.org/10.1155/2012/860619

[21] Elsayed EA, Omar HG, Abdel Galil S, El Enshasy HA. Optimization of fed-batch cultivation for extracellular $\alpha$ amylase production by Bacillus amyloliquefaciens in submerged culture. J Sci Ind Res 2016; 75: 480-6.

[22] Tham S, Ching D C, Huang H J, Lee Y F, H T S, Ching CC. Bioscience, biochemical characterization of an acid phosphatase from Thermos thermophiles. Biotechnol Biochem 2010; 74(4): 727-35.

https://doi.org//10.1271/bbb.90773

[23] Parhamfar M, Dalfard AB, Parhamfar M, Rad SF. Purification and characterization of an extracellular phosphatase enzyme From Bacillus spp. J Cell Mol Res 2016; 8(2): 90-7. https://doi.org/10.22067/jcmr.v8i2.58676

[24] Ullah HJA, Gibson MD. Purification and characterization of acid phosphatase from cotyledons of germinating soybean seeds. Arch Biochem Biophys 1988; 260(2): 514-20 https://doi.org/10.1016/0003-9861(88)90476-6

[25] Mohammed A. Purification and biochemical characterization of acid phosphatase from Vigna aconitifolia. Am J Plant Physiol 2010; 5(6): 361-70. https://doi.org/10.3923/ajpp.2010.361.370

[26] Sharma SB, Sayyed RZ, Trivedi MH, Gobi TA. Phosphate solubilizing microbes: sustainable approach for managing phosphorus deficiency in agricultural soils. Springer Plus 2013; 2: 587.

https://doi.org/10.1186/2193-1801-2-587

[27] Shekhar NC. An efficient microbiological growth medium for screening phosphate solubilizing microorganisms. FEMS Microbiol Lett 1999; 170(1): 265-70. https://doi.org/10.1111/j.1574-6968.1999.tb13383.x

[28] Shen J, Yuan L, Zhang J, Li H, Bai Z, Chen X, Zhang W, Zhang F. Phosphorus dynamics: From soil to plant. Plant Physiol 2011; 156: 997-1005.

https://doi.org/10.1104/pp.111.175232

Received on 30-09-2017

Accepted on 05-10-2017

Published on 31-12-2017

\section{DOl: https://doi.org/10.6000/1927-3037.2017.06.03.1}

(C) 2017 Danial and Alkhalf; Licensee Lifescience Global.

This is an open access article licensed under the terms of the Creative Commons Attribution Non-Commercial License (http://creativecommons.org/licenses/by-nc/3.0/) which permits unrestricted, non-commercial use, distribution and reproduction in any medium, provided the work is properly cited. 